\title{
Stricto sensu Nursing graduate programs' performance and the pursuit of excellence
}

\author{
Maria Lúcia do Carmo Cruz Robazzi
}

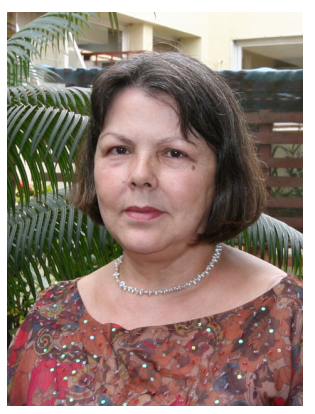

Last September, the result of the triennial evaluation was published, organized by the Coordination for the Improvement of Higher Education Personnel (CAPES) and carried out by representatives from several knowledge areas existing in the country.

In the Nursing field, the growth and strengthening of national graduate courses and the programs' concern with maintaining and/or raising its concepts was evidenced, aiming for greater visibility,

At the University of São Paulo at Ribeirão Preto College of Nursing (EERP-USP), the concepts were kept and/or raised and, currently, this institution offers two graduate programs, which were evaluated with grade 6 (the highest obtained so far by national Nursing graduate programs): the Fundamental Nursing program - which kept the grade obtained in the prior triennial evaluation - and Public Health Nursing, which rose from 5 to 6 . The others (Psychiatric Nursing and Interunit Doctoral Program, developed by the University of São Paulo School of Nursing along with EERP-USP) kept their grades at 5 , like in their prior evaluation. This excellent performance is a consequence of the advisors' and students' collective efforts, of the dedication and commitment of the program coordinators and of the Graduate Program Commission; of the institutional support, including the Office of the Pro-Rector of Graduate Studies of the University of São Paulo, among other contributive elements.

When it comes to the Nursing field in Brazil, in the 2004/2006 evaluation, the 32 existing programs obtained the following grades: 13 grade $3(40.6 \%), 9$ grade $4(28.1 \%), 9$ grade $5(28.1 \%)$ and 1 concept $6(3.1 \%)^{(1)}$. In the recently finished evaluation (2007/2009), the results of 41 programs were: $31.4 \%$ with concept 3 ; equal percentages with concepts 4 and 5 , besides $5.7 \%$ with concept $6^{(2)}$. These results show the growth of the area in both quantitative and qualitative terms.

Brazilian nursing earns space and consolidates itself in human resource training in research by graduating masters in nursing science, since the early 70's, and PhDs, since the early 80's. It has been growing in numbers of stricto sensu programs and programs' expansion, as well as in the qualified production of advanced scientific or technological knowledge, published in relevant journals, and in the training of qualified human resources. The existing programs are structured with areas centered in the Nursing course, consolidated in their unit and specificity of knowledge field. The 41 stricto sensu nursing programs, accredited by CAPES, represent 38 Academic Master's Programs, 21 Doctoral Programs and 3 Professional Master's(2).

It is known, however, that there is still a lot to be done, collectively, to enhance and strengthen the Nursing field in Brazil. The many challenges include: greater efforts to seek the graduated professionals, to know by which sectors of the labor market they were absorbed, greater efforts concerning the internationalization process, searching the excellence the Nursing Graduate area already reached in more developed countries; greater fundraising capacity to 
carry out projects that support the development and strengthening of the research lines; better training of the stricto sensu graduate faculty by increasing post-doctoral programs in excellence centers abroad; greater collective efforts in PhDs training because, even though its growth has been important ${ }^{(3)}$, there is still a lack in many regions of the country. It is noteworthy that, although scientific production increased(3), greater visibility is needed, by publishing in foreign journals with high impact factors.

Another aspect that deserves, indeed, to be highlighted, is the need for a better geographical distribution of Graduate stricto sensu Programs in Brazil, in view of their bad, asymmetrical distribution, similar to other areas ${ }^{(4)}$, with important concentration in the Southeast region.

Hard work, collective effort, solidarity of the stronger programs with the developing ones, more resources by qualified entities and greater effort by universities are surely necessary stages to face and defeat the challenges and minimize the problems in the Nursing area. The collective construction of a national target plan for stricto sensu Nursing Graduate Programs, with objectives that are precise and agreed upon by representatives, coordinators, professors and graduate students, with deadlines being kept, may be possible in one of the steps, so that, in the future, most graduate programs in Brazil reach the desired excellence.

The Latin American Journal of Nursing, as a scientific promotion organ of the EERP-USP and the WHO Collaborating Centre for Nursing Research Development, has contributed, indeed, to spread knowledge produced at the Nursing graduate program.

\section{References}

1. Capes. Relatório Anual: Avaliação Continuada - 2006 - Ano Base 2005. Área de Avaliação: enfermagem. 2006, 7 p. [acesso 25 set 2010]. Disponível em: http://www.capes.gov.br/images/stories/download/avaliacao/DocArea_Enfermagem_Anobase2005.pdf

2. Capes. Documento de Área 2009. Área de Avaliação: Enfermagem. 13 p. [acesso 25 set 2010]. Disponível em: http://www.capes. gov.br/images/stories/download/avaliacao/ENFERMAGEM_22jun10b.pdf.

3. Rodrigues RAP, Erdmann AL, Silva IA, Fernandes JD, Araújo TL, Vianna LAC, et al. Doctoral education in nursing in Brazil. Rev. Latino-Am. Enfermagem [Internet]. ago 2008. [acesso 27 set 2010];16(4):665-71. Disponível em: http://www.scielo.br/scielo. php?script=sci_arttext\&pid=S0104-11692008000400003\&lng=en\&nrm=iso\&tlng=en

4. Carvalheiro JR. Janus bifronte e a pós-graduação. Ciênc Saúde Colet. 2010;15(4):1908-16.

Maria Lúcia do Carmo Cruz Robazzi is member of the Editorial Board of the Latin American Journal of Nursing, and Full Professor of the University of São Paulo at Ribeirão Preto College of Nursing, WHO Collaborating Centre for Nursing Research Development, Brazil, e-mail: avrmlccr@eerp.usp.br. 